\title{
ELABORATION AND EVALUATION OF A NEW SCREENING MEDIUM FOR DETECTION AND PRESUMPTIVE IDENTIFICATION OF EXTENDED- SPECTRUM $\beta$-LACTAMASE-PRODUCING ORGANISMS (ESBL)
}

\author{
Carlos Henrique Pessôa de Menezes e Silva ${ }^{1,2 *}$ \\ ${ }^{1}$ Setor de Microbiologia - Marcos Daniel Laboratório, Vitória, ES, Brasil \\ ${ }^{2}$ Departamento de Patologia - Universidade Federal do Espírito Santo (UFES), Vitória, ES, Brasil
}

Submitted: November 24, 1999; Returned to authors for corrections: July 17, 2000; Approved: November 07, 2000

\begin{abstract}
The new B-lactamases have arisen largely as a consequence of heavy use of new expanded spectrum $\beta$ lactam antibiotics. Health professionals need to be aware of the resistance problems caused by the new enzymes, and know the correct procedures to detect, prevent and control such problems. In this study, a new screening medium called Ceftazidime-Inositol-Vancomycin-Amphotericin B Agar (CIVA) was elaborated and the microbiological performance was evaluated for the detection and presumptive identification of ESBLproducing members of Enterobacteriaceae. It was performed in 126 stool samples from hospitalized patients at Santa Monica Hospital (Vila Velha, ES, Brazil), who had been heavily exposed to broad-spectrum antibiotic combinations. The bacteria were detected by the medium based on their colony colours (due to inositol fermentation). Additional tests were required for correct identification of these strains. No false positive rates were detected.
\end{abstract}

Key words: Enterobacteriaceae; culture medium; ESBL

\section{INTRODUCTION}

Extended-spectrum $\beta$-lactamases (ESBLs) represent a major group of $\beta$-lactamases currently being world-widely identified in large numbers. Extended-spectrum $\beta$-lactamaseproducing organisms contain multiresistant plasmids that may be easily transmitted among members of the Enterobacteriaceae, even in the same patient. As a result, ESBL-producing organisms are resistant to a variety of classes of antibiotics $(3,11,12)$.

The most noticeable feature of these enzymes is their ability to attack extended spectrum cephalosporins (e.g., ceftazidime, cefotaxime and ceftriaxone), monobactams such as aztreonam, narrow spectrum cephalosporins (e.g., cephalotin) and anti-Gram-negative penicillins (e.g., piperacilin) $(5,10)$. It must be mentioned, though, that
Carbapenems such as imipenem are not affected by these enzymes and that clavulanic acid inhibits their action $(2,9,15)$.

The organisms that produce ESBLs in most centers are primarily Klebsiella pneumoniae and Escherichia coli $(6,8)$. However, ESBL-producing Enterobacter spp., Proteus spp. and other Enterobacteriaceae (including Citrobacter spp., K.ozaenae, K.oxytoca, Morganella morganii, Salmonella spp. and Serratia marcescens) have also been reported to cause nosocomial outbreaks $(5,14,15)$.

The highest risks of infection with ESBL-producing are: prolonged hospitalization, high score of severe illnesses, recent surgery, instrumentation, admission to an intensive care unit (16), catheterization, total antibiotic days, combination of antibiotic therapy with a quinolone, drugs active against anaerobes and treatments with 2nd- or 3rd-gen cephalosporins or extended-spectrum penicillins $(1,4,13)$.

\footnotetext{
* Corresponding author. Mailing address: Rua Fortunato Ramos, 123, Santa Lúcia, Vitória, ES, Brasil. Phone: (+5527) 200-3737. E-mail: chpmsrtz@terra.com.br
} 
The effects of the non-identification of ESBL-producing organisms may result in an inaccurate evaluation of antimicrobial susceptibility, followed by an inappropriate dosing of expanded-spectrum antibiotics $(7,9)$.

In this study, a new screening medium called CeftazidimeInositol-Vancomycin-Amphotericin-B (CIVA) Agar was elaborated and the microbiological performance was evaluated for the detection and presumptive identification of ESBLproducing members of Enterobacteriaceae.

\section{MATERIALS AND METHODS}

Both detection and presumptive identification of ESBLproducing members of Enterobacteriaceae were performed in 126 stool samples from hospitalized patients at Santa Monica Hospital (Vila Velha/ES, Brazil) who had been heavily exposed to broad-spectrum antibiotic combinations. The laboratorial tests were performed at the microbiology section of the Marcos Daniel Laboratory (Vitória, ES, Brazil).

CIVA Agar is a mixture of antimicrobials to which growth factors and stable nutrients are added. The addition of Vancomycin and Amphotericin-B allowed the inhibition of Grampositives and yeasts respectively.

Formula per liter of purified water:

- Peptone of Casein: $11.0 \mathrm{~g}$

- Beef extract: $3.0 \mathrm{~g}$

— Inositol: $12.0 \mathrm{~g}$

— Sodium chloride: $8.5 \mathrm{~g}$

- Bromothymol blue: $0.03 \mathrm{~g}$

- Agar: $17.0 \mathrm{~g}$

- Final $\mathrm{pH}=7.0$

All the ingredients were dissolved in purified water and mixed thoroughly. The mixture was sterilized by autoclavation at $121^{\circ} \mathrm{C}$ for 15 minutes. Then, the base was cooled to approximately $50^{\circ} \mathrm{C}$ and the antimicrobials were added. The medium was dispensed into sterilized Petri plates and stored at $8^{\circ} \mathrm{C}$.

The nutrients in CIVA Agar are supplied by peptone and beef extract. Inositol is included as a differential component and an energy source for the organisms capable of its utilization by a fermentation mechanism.

The incorporation of the antimicrobial agents, Ceftazidime (2 mg/L), Vancomycin (10 mg/L) and Amphotericin-B (4,5 mg/ L) suppresses the growth of the normal microbial flora in fecal specimens.

The medium is differential because of the ability of ESBLproducing organisms to grow under a Ceftazidime concentration $(2 \mu \mathrm{g} / \mathrm{mL})$. Another differencial feature is the presumptive identification of these organisms due to inositol fermentation by some species or genera, lowering the $\mathrm{pH}$ of the medium making the bromthymol blue indicator turn the colonies and the surrounding medium yellow.

Stool samples received for culture were plated on CIVA Agar. The plates were inoculated with a non-calibrated loop and incubated in ambient air at $35-37^{\circ} \mathrm{C}$ for a minimum of $24 \mathrm{~h}$ before initial examination. Culture workup on the plate was performed following the standard protocols used in our laboratory. Plates demonstrating no growth in a primary examination were incubated for more $24 \mathrm{~h}$. The following information was recorded for each colony type growing on CIVA Agar: colony size, colony color, intensity of colony pigmentation and any pigmentation of the media.

A comparative degree with another screening method was performed in all samples (inoculation on MacConkey Agar supplemented with $2 \mathrm{mg} / \mathrm{L}$ of Ceftazidime) (17), incubated for $48 \mathrm{~h}$ at $35-37^{\circ} \mathrm{C}$. Despite this comparative study, MacConkey Agar with Ceftazidime is not a standardized method for isolation of ESBL-producing Enterobacteriaceae.

Even when presumptive identifications were obtained from the use of the described tests, other biochemical tests were performed to confirm the species isolated making use of the standard microbiology methods used in our laboratory (MicroScan Auto-SCAN-4 ${ }^{\circledR}$ Dade-Behring System). All isolates which grew on CIVA Agar and on MacConkey Agar with Ceftazidime were tested by the use of MicroScan Neg Combo-20 panel. To validate the use of CIVA Agar for antimicrobial selectivity, MicroScan susceptibility tests (using the same panel) were performed parallely to the identifications and the isolates were tested for ESBL expression by the double-disk synergy test performed with Ceftazidime, Ceftriaxone, Aztreonam and Amoxicilin plus clavulanic acid disks.

\section{RESULTS}

A total of 126 stool samples were tested in this study. Twenty-seven $(21.4 \%)$ contained organisms which grew on CIVA Agar and on MacConkey Agar with Ceftazidime. These were initially identified as ESBL-producing organisms. Nineteen (70.4\%) grew within $24 \mathrm{~h}$ while eight (29.6\%) grew only after an additional incubation period of $24 \mathrm{~h}$, on both media. Ninetynine cultures $(78.6 \%)$ had no growth on the cited media after $72 \mathrm{~h}$ of incubation.

Table 1 shows the bacteria isolated from the stool samples.

Bacteria other than Enterobacteriaceae, such as Pseudomonas spp., which grew on CIVA Agar and on MacConkey Agar with Ceftazidime, were not included in this study.

Table 2 shows the characteristics of each genus on the medium. 
Table 1. Distribution of ESBL-producing strains among the isolated enterobacterial species.

\begin{tabular}{lcc}
\hline ORGANISMS & NUMBER OF ISOLATES & $\%$ \\
\hline Klebsiella spp. & 11 & 40.74 \\
Escherichia coli & 06 & 22.22 \\
Enterobacter spp. & 05 & 18.52 \\
Serratia spp. & 03 & 11.11 \\
Citrobacter koseri & 01 & 3.7 \\
Proteus vulgaris & 01 & 3.7 \\
\hline
\end{tabular}

Table 2. Characteristics of the Enterobacteriaceae isolated on CIVA Agar.

\begin{tabular}{ll}
\hline ISOLATES & CHARACTERISTICS \\
\hline Klebsiella spp. & Yellow, extremely mucoid colonies \\
Escherichia coli & Large, flat, colorless colonies \\
Enterobacter spp. & Yellow colonies \\
Serratia spp. & Pale yellow colonies \\
Citrobacter koseri & Opaque, colorless colonies \\
Proteus vulgaris & Large, colorless colonies \\
\hline
\end{tabular}

\section{DISCUSSION}

Klebsiella spp., some strains of Enterobacter spp. and Serratia spp. were detected by the medium based on their colony colours (due to inositol fermentation). Citrobacter spp., Proteus vulgaris and Escherichia coli ESBL-producing grew well on the medium and were distinguished by the absence of inositol fermentation.

The advantage of CIVA Agar medium was the direct identification of ESBL-producing organisms from a single primary isolation plate. Rapid and presumptive identification of the most common organisms of this group was easily obtained.

The use of CIVA Agar allowed for less time and cost of ESBL-producing organisms isolation and presumptive identification than our conventional method using MacConkey Agar with Ceftazidime, mainly because CIVA Agar inhibits the growth of yeasts which may be present in stool samples from hospitalized patients, thereby facilitating isolation of ESBLproducing organisms.

CIVA Agar was easily adapted into our laboratory workflow. The combination of its presumptive identification and MicroScan system improved turn around time and cost of reportable results.

We propose the use of CIVA Agar, which can be considered for use as a primary isolation agar for specimens from hospitalized patients without the need for subcultures to help researchers overcome many of the difficulties associated with the screening of ESBL-producing Enterobacteriaceae.

\section{ACKNOWLEDGMENTS}

Marcos Daniel Laboratory for supplying all the elements for the research.

\section{RESUMO}

\section{Elaboração e avaliação de um novo meio de triagem para a detecção e identificação presuntiva de enterobactérias produtoras de $\beta$-lactamase de espectro estendido (ESBL)}

As novas $\beta$-lactamases têm aparecido, na maioria das vezes, como consequência do amplo uso de antibióticos $\beta$-lactâmicos de largo espectro. Os profissionais de saúde precisam estar atentos acerca do problema da resistência bacteriana causado por estas novas enzimas e conhecer os corretos procedimentos para detectar, prevenir e controlar tais situações. Neste estudo, um novo meio de triagem foi desenvolvido no setor de Microbiologia do Marcos Daniel Laboratório - Vitória, ES (denominado CIVA - Ceftazidima-Inositol-VancomicinaAnfotericina B) e a sua performance microbiológica foi avaliada quanto à detecção e identificação presuntiva de enterobactérias produtoras de ESBL. Foram realizadas 126 culturas de amostras fecais de pacientes hospitalizados no Hospital Santa Monica (Vila Velha, ES, Brasil), previamente expostos a combinações de antibióticos de largo espectro. As bactérias foram detectadas pelo meio baseado nas cores das colônias desenvolvidas (devido à fermentação do inositol). Testes adicionais foram realizados para a correta identificação destes microorganismos. Não foram detectados resultados falso-positivos.

Palavras-chave: enterobactérias, meio de cultura, ESBL

\section{REFERENCES}

1. Bauernfeind, A.; Stemplinger, I.; Jungwirth, R.; Giamarellou, H. Characterization of the plasmidic $\beta$-lactamase CMY-2, which is responsible for cephamycin resistance. Antimicrob. Agents Chemother. 40:221-224, 1996.

2. Bauernfeind, A.; Stemplinger, I.; Jungwirth, R.; Ernst, S.; Casellas, J. M. Sequences of $\beta$-lactamase genes encoding CTX-M-1 (MEN-1) and CTXM-2 and relationship of their amino acid sequences with those of other $\beta$-lactamases. Antimicrob. Agents Chemother. 40:509-513, 1996

3. Curtis, N. A. C.; Eisenstadt, R. L.; Rudd, C.; White, A. J. Inducible type I $\beta$-lactamases of Gram-negative bacteria and resistance to $\beta$ lactam antibiotics. J. Antimicrob. Chemother. 17:51-61, 1986.

4. DuBois, S. K.; Marriott, M. S.; Amyes, S. G. B. TEM-and SHV-derived extended-spectrum $\beta$-lactamases: relationship between selection, structure and function. J. Antimicrob. Chemother. 35:7-22, 1995. 
5. Fournier, B.; Roy, P. H.; Lagrange, P. H.; Philippon, A. Chromosomal $\beta$ lactamase genes of Klebsiella oxytoca are divided into two main groups, bla OXY-1 and bla OXY-2. Antimicrob. Agents Chemother. 40:454-459, 1996.

6. Heritage, J.; Hawkey, P. M.; Todd, N.; Lewis, I. J. Transposition of the gene encoding a TEM-12 extended-spectrum -lactamase. Antimicrob. Agents Chemother. 36:1981-1986, 1992.

7. Kado, C. I.; Liu, S. T. Rapid procedure for detection and isolation of large and small plasmids. J. Bacteriol. 145:1365-1373, 1981.

8. Lemozy, J.; Sirot, D.; Chanal, C.; Huc, C.; Labia, R.; Dabernat, H. et al. First characterization of inhibitor-resistant TEM(IRT) $\beta$-lactamases in Klebsiella pneumoniae strains. Antimicrob. Agents Chemother., 39:2580-2582, 1995.

9. Livermore, D. M. $\beta$-Lactamases in laboratory and clinical resistance. Clinical Microbiology Reviews. 8:557-584, 1995.

10. M'Zali, F.-H.; Gascoyne-Binzi, D. M.; Heritage, J.; Hawkey, P. M. Detection of mutations conferring extended-spectrum activity on SHV b-lactamases using polymerase chain reaction single strand conformational polymorphism (PCR-SSCP). J. Antimicrob. Chemother. 37:797-802, 1996.

11. Mabilat, C.; Goussard, S.; Sougakoff, W.; Spencer, R. C.; Courvalin, P. Direct sequencing of the amplified structural gene and promoter for the extendedbroad-spectrum $\beta$-lactamase TEM-9 (RHH-1) of Klebsiella pneumoniae. Plasmid 23:27-34, 1990
12. Nuesch-Inderbinen, M.; Hachler, H.; Kayser, F. H. New system based on site-directed mutagenesis for highly accurate comparison of resistance levels conferred by SHV b-lactamases. Antimicrob. Agents Chemother. 39:1726-1730, 1995

13. Piddock, L. J. V.; Jin, Y. F.; Turner, H. L. Activity of 13 -lactams combined with BRL 42715 against $\beta$-lactamase producing Gram-negative bacteria compared to combinations with clavulanic acid, tazobactam and sulbactam. J. Antimicrob. Chemother 31:89-103, 1993.

14. Piddock, L. J. V.; Traynor, E. A.; Wise, R. A comparison of the mechanisms of decreased susceptibility of aztreonam-resistant and ceftazidime-resistant Enterobacteriaceae. J. Antimicrob. Chemother. 26:749-762, 1990.

15. Quinn, J. P. Clinical significance of extended-spectrum $\beta$-lactamases. European J. Clin. Microbiol. Infec. Dis. 13:39-42, 1994.

16. Robillard, N. J. Broad-host-range gyrase A gene probe. Antimicrob. Agents Chemother. 34:1889-1894, 1990.

17. Wiener, J.; Quinn, J. P.; Bush, K.; Bradford, P. A. et al. Multiple antibioticresistant Klebsiella and Escherichia coli in nursing homes. J. Am. Med. Assoc. 6:517-523, 1999. 